\title{
Long-Term Management of Kosi River Basin
}

$\operatorname{AUTHOR}(S)$ :

Regmi, Balmukunda

\section{CITATION:}

Regmi, Balmukunda. Long-Term Management of Kosi River Basin. Kyoto Conference Proceedings (The Tenth International Symposium on Mitigation of Geo-disasters in Asia 2012: 1-10: 共同研究（一般研究集会）24K-02.

ISSUE DATE:

2012-10-07

URL:

http://hdl.handle.net/2433/180441

RIGHT: 


\title{
Long-Term Management of Kosi River Basin
}

\author{
Balmukunda Regmi
}

\begin{abstract}
Kosi River starts from Tibet in China, gains momentum in Nepal, enters India to join the Ganges. Kosi is a young river. Chatara as nodal point, Kosi had shifted westward for about $120 \mathrm{~km}$ in past 250 years showing a cone $(80 \mathrm{~km}$ long and $150 \mathrm{~km}$ wide alluvial fan) building activity, prior to its embankment in 1959 . The major aim of Kosi barrage was to control flood in Bihar; irrigation, hydroelectricity generation, land reclamation, fishing and navigation were less important. Although it prevented major floods in Bihar for about 50 years, the Project was disputed. Some scholars also raised environmental and safety concerns. Kosi is a heavy sediment carrying river ( 80 million $\left.\mathrm{m}^{3} / \mathrm{year}\right)$. So far no effective method has been developed to avoid siltation upstream of the barrage. The riverbed continued to rise at about $0.05 \mathrm{~m}$ per year leading to a situation when it was 4-5 m above the land outside the embankments. Due to sloping landscape, Kosi breached eastern bank in its weakest part and followed some of its old channels. The 2008 flood took 527 lives, inundated 116,000 ha of land and left 234,000 people homeless. The 2008 Kosi flood has been considered as manmade for failure to address the sedimentation problem upstream of the barrage with effective counter measures, no regular repair and maintenance work of the upstream embankments and delay in opening the barrage gates. As a solution, India is lobbying for Kosi $269 \mathrm{~m}$ high dam $40 \mathrm{~km}$ north of present barrage. The proposal first suggested in 1937 has been opposed by Nepalese scholars. Scientific researches on the ways to reduce the sediment load from upstream and to increase the silt clearing capacity downstream are needed. Nepal-China-India trilateral close cooperation is called for producing a long-term solution.
\end{abstract}

Keywords Kosi river basin (KRB) - Integrated flood management - Kosi flood

\footnotetext{
B. Regmi $(\bowtie)$

Tribhuvan University, Kathmandu, Nepal

e-mail: bmregmi@iom.edu.np; bmregmi@yahoo.co.uk
} 
Fig. 1 Saptakosi River watershed (Source Salman and Uprety 2002)

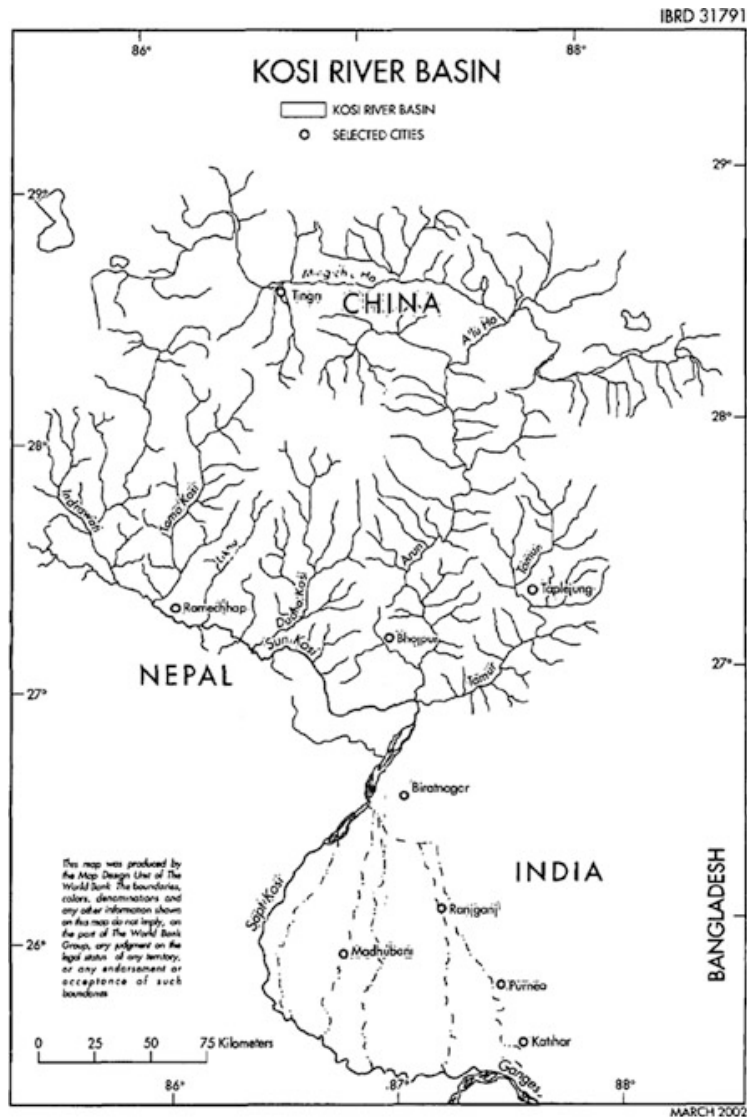

\section{Introduction}

Kosi River starts from Tibet in China, gains momentum in Nepal where it becomes Saptakosi at Chatara, enters India to join the Ganges, as shown in Fig. 1. It has total catchment area of $69,300 \mathrm{~km}^{2}\left(29,400 \mathrm{~km}^{2}\right.$ in China, $30,700 \mathrm{~km}^{2}$ in Nepal and $9,200 \mathrm{~km}^{2}$ in India). Its watershed includes parts of south Tibet north of Mount Everest and the eastern third of Nepal (Kattelmann 1991). Termed "Sorrow of Bihar", Kosi is a young river. Chatara as nodal point, Kosi had shifted westward for about $120 \mathrm{~km}$ in past 250 years showing a cone $(80 \mathrm{~km}$ long and $150 \mathrm{~km}$ wide alluvial fan) building activity (See Fig. 2), prior to its embankment in 1959 and completion of barrage in 1964 following the severe floods in 1953-1954 and subsequent Indo-Nepal Kosi Treaty of 1954.

Through the history, Kosi River has been mainly described as an untameable river that had given northern Bihar continuous problems and solutions are still 
Fig. 2 Position of Kosi River taken from 11 selected historical maps. The channel positions shown in this diagram, illustrate an eastwest oscillating movement of Kosi channel (modified after Gole and Chitale 1966)

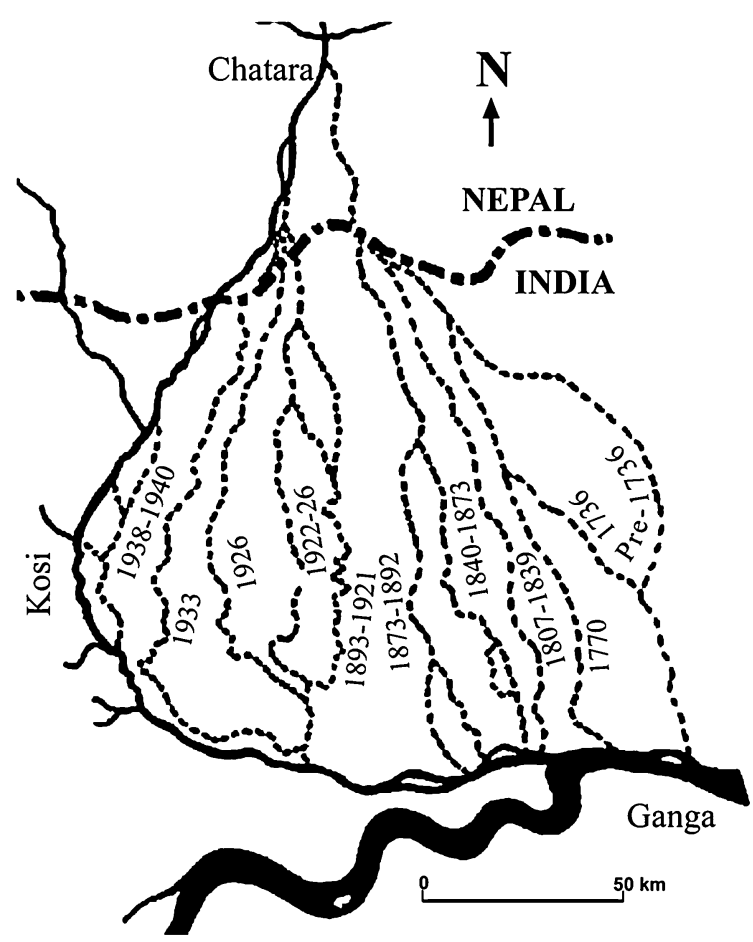

being developed to cope with the challenge. So far efforts in the past, especially the 1959 embankment, have brought positive results in dealing with Kosi River. Compared to regular inundations and floods, post-barrage events including the 2008 flood are less severe. However, the embankments have failed in many instances, as listed in Table 1.

\section{Was There Human Factor in Kosi Flood 2008?}

As early as 1966, scientific concerns were shown that the flood embankments could not prevent the shifting tendency of the Kosi course (Gole and Chitale 1966). Although it prevented major floods in Bihar for about 50 years, the Project was disputed. Many scientists continued to caution that Kosi barrage was on verge of breach; worries had been expressed that a disaster was inevitable; the 2008 flood rectified their concerns: it took 527 lives, inundated 116,000 ha of land and left 234,000 people homeless. Figure 3 shows the breached portion and Fig. 4 shows the flow of Kosi during 2008 flood.

Kosi is a heavy sediment carrying river ( 80 million $\mathrm{m}^{3} /$ year) due to cloudburst, Asian monsoon, masswasting, and Himalayan landslides (Shrestha et al. 2010). No effective measure had been taken to avoid siltation upstream of the barrage. With 
Table 1 Breaches in the Kosi embankments

\begin{tabular}{|c|c|c|}
\hline Years & Place breached & Remarks \\
\hline 1963 & Dalwa (Nepal) & No casualty \\
\hline 1968 & Near Jamalpur in Darbhanga district & \\
\hline 1971 & $\begin{array}{l}\text { Bhatania approach bund downstream } \\
\text { of Bhimnagar }\end{array}$ & \\
\hline 1980 & Near Bahuarawa in Saharsa district & $\begin{array}{l}\text { Eroded the eastern embankment but water receded } \\
\text { quickly after the breach }\end{array}$ \\
\hline 1984 & $\begin{array}{l}\text { Near Hempur village in Saharsa } \\
\text { district }\end{array}$ & $\begin{array}{l}\text { Eastern embankment. Affected } 50 \text { lakhs of people } \\
\text { in Saharsa and Supaul districts }\end{array}$ \\
\hline 1987 & $\begin{array}{l}\text { Samani and Ghoghepur villages of } \\
\text { the Mahisi block of Saharsa } \\
\text { district }\end{array}$ & Western embankment \\
\hline 1991 & Joginia & $\begin{array}{l}\text { Eroded the embankment for a stretch of about } \\
2 \mathrm{~km} \text {, but receded without causing any damage }\end{array}$ \\
\hline 2008 & Kusaha (Nepal) & $\begin{array}{l}\text { Affected approximately } 3,000 \mathrm{sq} \mathrm{km} \text { of area; a } \\
\text { number of houses, schools, roads, and } \\
\text { hospitals were damaged due to the flow of the } \\
\text { river. A total of } 33,45,545 \text { people and } 7,12,140 \\
\text { animals from } 993 \text { villages of } 412 \text { panchayats } \\
\text { of } 35 \text { blocks of } 5 \text { districts were affected out of } \\
\text { which } 239 \text { humans and } 1,232 \text { animals lives } \\
\text { were lost }\end{array}$ \\
\hline
\end{tabular}

Source Sinha 2009

help of satellite images and a field visit, Sinha (2009) has concluded that the river has been moving towards the eastern embankment around Kusaha region at least since 1979 and a breach in the embankment at Kusaha was detected as early as 5th August 2008, that a well-defined seepage channel parallel to the eastern afflux bund formed some years ago. The surveys in 1963 and 197 upstream of the barrage showed that the riverbed continued to rise at about $0.05 \mathrm{~m}$ per year (Thapa 2004). The river bed around the western afflux bund was observed to be at least 4-5 m higher than the surrounding floodplain level (Mishra 2008; Dixit 2008; Sinha 2009) (See Fig. 5). Due to sloping landscape it was normal for Kosi to breach eastern bank in its weakest part and follow some of its old channels. Worries had been expressed that such a disaster was inevitable; the 2008 flood rectified their concerns: it took 527 lives, inundated 116,000 ha of land and left 234,000 people homeless.

At least three points indicate the 2008 Kosi flood as manmade: failure to address the sedimentation problem upstream of the barrage with effective counter measures, no regular repair and maintenance work of the upstream embankments, and the breach of embankment at a discharge of 144,000 cusecs (cubic feet per second), far below its maximum designed capacity of 950,000 cusecs, due to delay in opening the barrage gates.

Inadequacy of proper communication has been demonstrated by some field research scientists in relation to failure in containing the Kosi floods. (Shrestha 


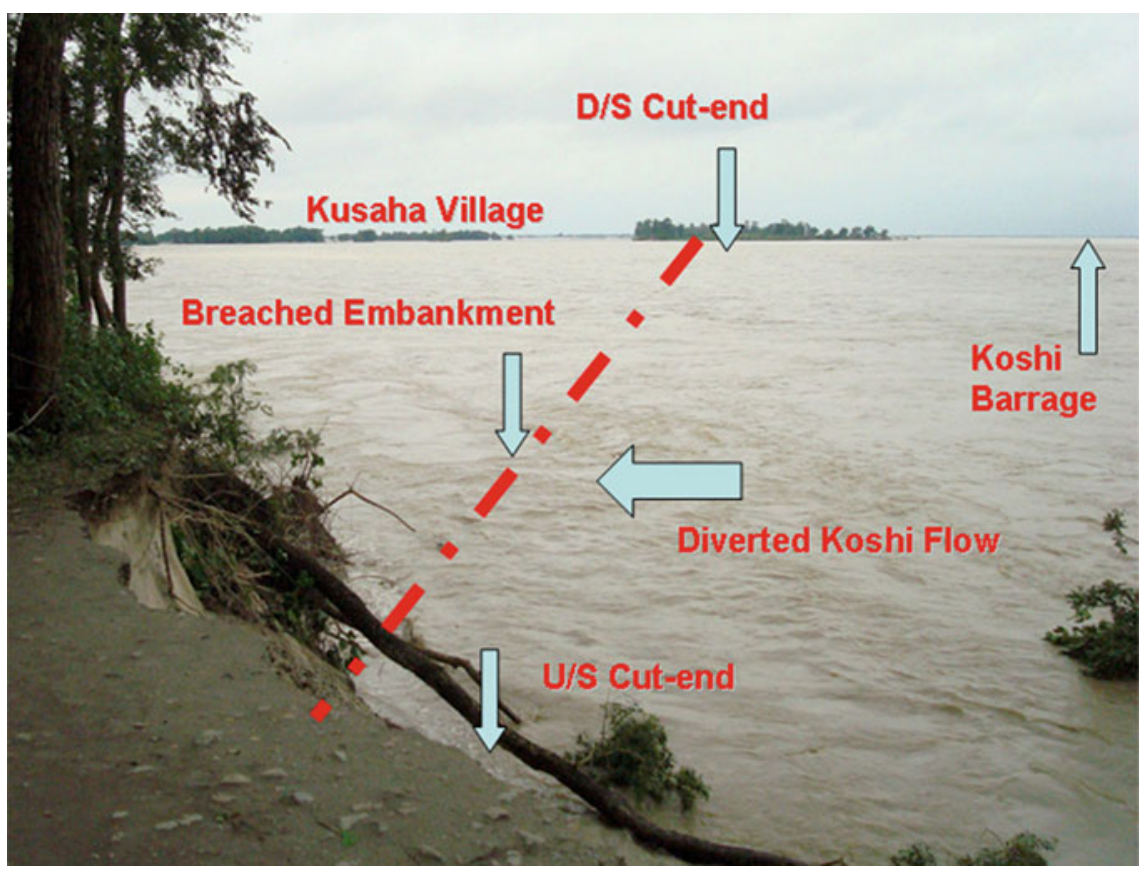

Fig. 3 Kosi flowing in breached portion (Pun 2009)

et al. 2009) (Fig. 6). These include irregularities in working meetings of concerned joint committees and field inspections/monitoring of the barrage.

\section{Challenges with Proposed Kosi High Dam}

As a solution to the failing Kosi project, India is lobbying for Kosi $269 \mathrm{~m}$ high dam $40 \mathrm{~km}$ north of present barrage. The proposal first suggested in 1937 has been opposed by Nepalese scholars on many accounts: similar siltation problem, lifespan of just 37 years (versus 25 years that of present barrage), submergence of about $324 \mathrm{~km}^{2}$ of Nepal's fertile river valleys displacing over 75,000 people, and increased possibility of earthquakes in already seismically vulnerable area.

The fact that Nepal is a seismically vulnerable zone is well established. Bilham (1995) has presented some major earthquakes in the Himalayas as given in Fig. 7. 


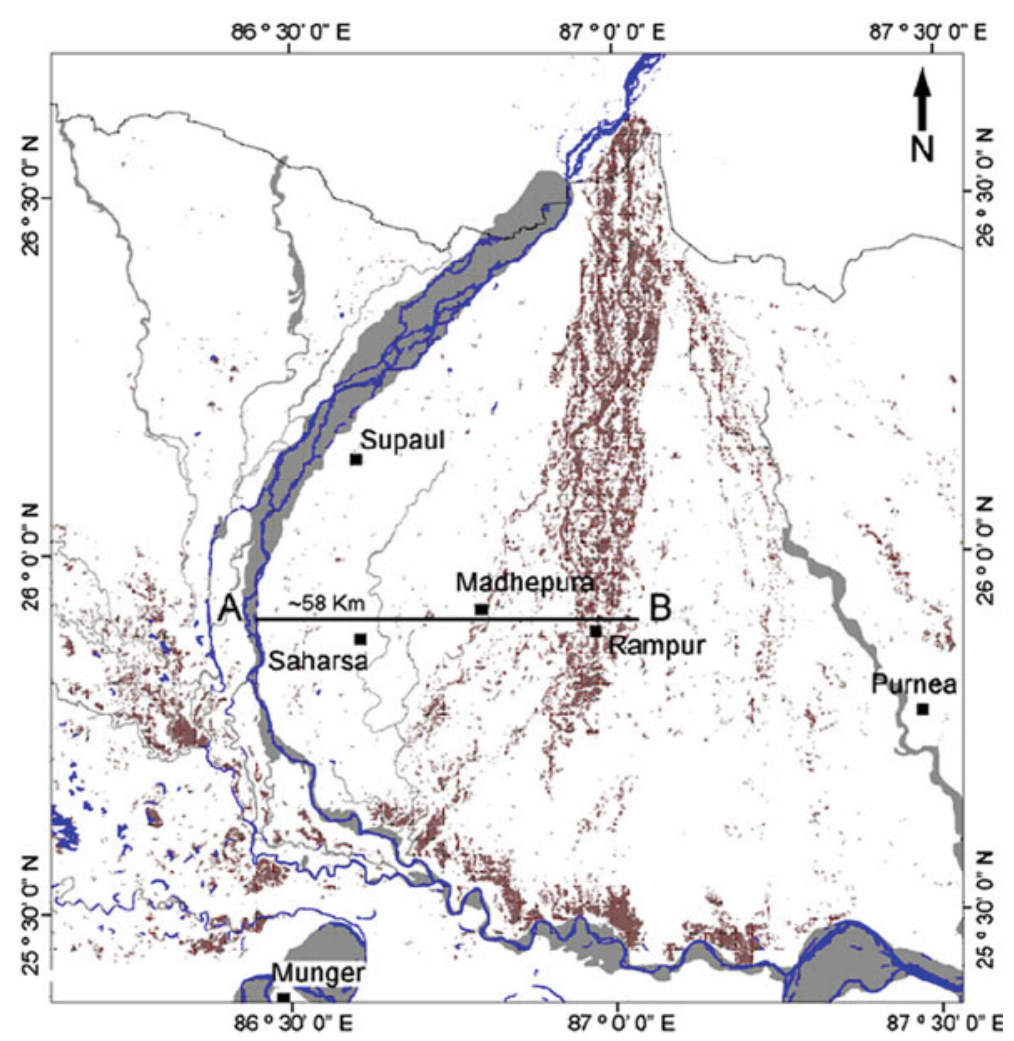

Fig. 4 Kosi megafan showing the flood water flow path after the August 2008 avulsion (after NRSA, http:www.//fmis.bih.nic.in/Kosi_Flood\%20Map/aug22-23_Bihar-Nepal-map.pdf). Note a shift of the Kosi channel by about $60 \mathrm{~km}$ to the east (as measured along AB). (Chakraborty et al. 2010)

\section{The Way Ahead}

Kosi River is not just a source of problems; it is also a resource that has immense potential for utilization in economic development. It supplies water to the densely populated South Asia_-screening the Department of. Hydrology and. Meteorology, Nepal records from 1977 to 2008 showed its minimum water flow was 6526 cusecs (28 March 2001) and an average discharge of 1564 cumecs. It can fulfil the household and agricultural needs of southern Nepal, Bihar and significant part of nearby areas of India. Besides, it has a potential for hydroelectricity generation of 22,350 MW (of which 10,860 MW is economically exploitable) and it also provides the best option for waterway to landlocked country.

Prudent approach to minimize the Kosi problems would be carrying out scientific research on the ways to reduce the sediment load from upstream and to increase the silt clearing capacity of the river downstream. Nepal-China-India trilateral close cooperation is called for producing a long-term solution. 


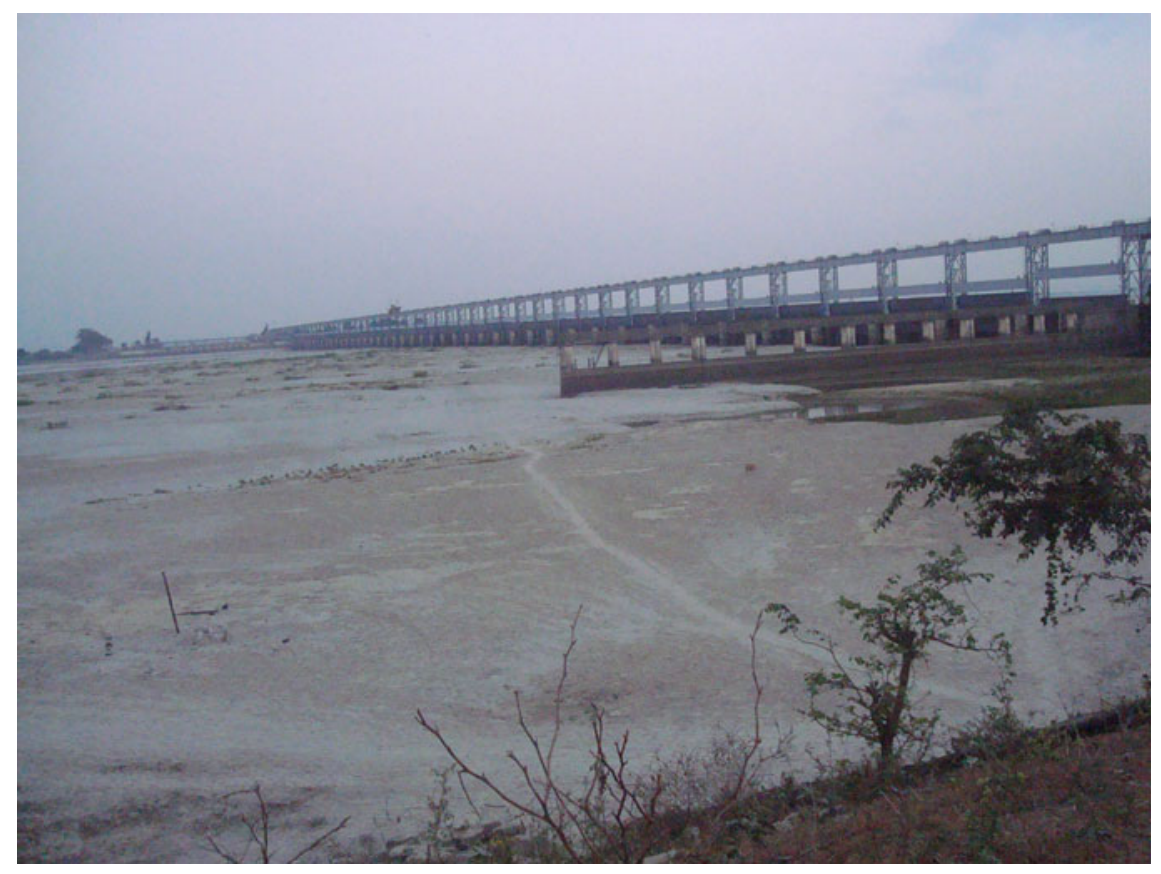

Fig. 5 Dry Kosi barrage (Pun 2009)

The problem of Kosi flooding is a problem of sediment (Durham Report 2011). Any solution which can deal with sediment that the river supplies to the plains of Bihar will also address issue of unexpected and catastrophic shifts in the river, as occurred in 2008.

The management of Kosi River Basin can benefit from a new "sediment transport system" adopted by Japan that proposed the outline of sediment management policy_integrated sediment system management-in the future in July 1998 by considering all aspects, from mountains include forests to shorelines, and proposed the promotion of total sediment management (Kashiwai 2005) along with the following strategies for specific areas: Areas upstream Mountain and foot of a mountain area, alluvial fan-steep and rapid flow; Hillside works: reducing sediment yield from hillside slope; Check dam: conserving forest area, preventing excess sediment flow to areas downstream; Retarding basin: preventing excess sediment flow to areas downstream; Countermeasures for reservoir sedimentation: reducing reservoir sedimentation. Areas downstream foot protection works: stabilizing embankment; groundsill: preventing scoring, stabilizing riverbed; prohibition of sand and gravel removal: preventing riverbed degradation; riverbed excavation: preventing riverbed aggradations, conserving water quality; spur dike: restoration of pools. 


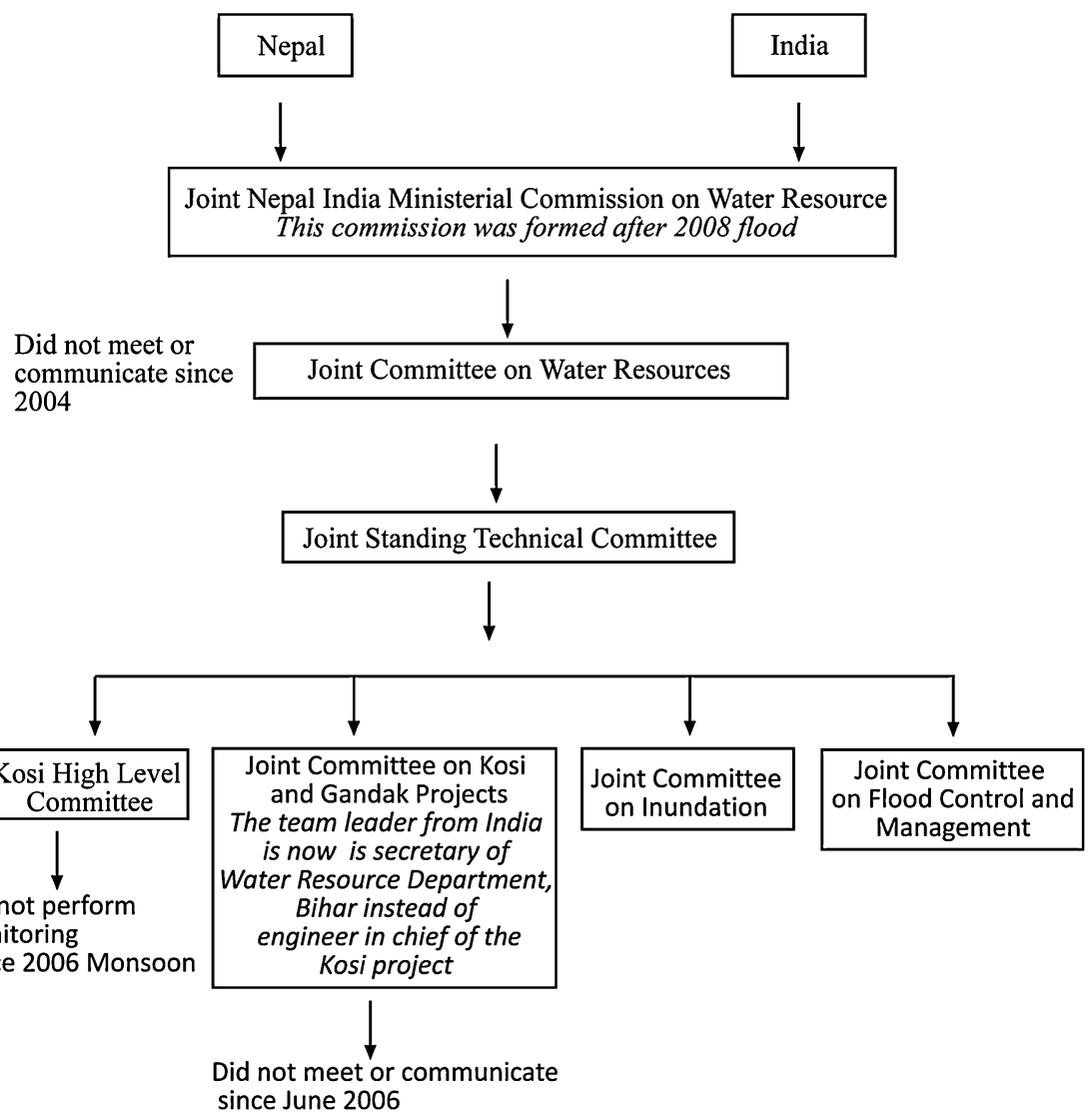

Fig. 6 Communication gaps prior to Kosi flood 2008 (modified after Shrestha et al. 2009)

There is a need to work with the river to allow some degree of dynamic behaviour, but in a way that does not compromise the people and communities on the fan (Kashiwai 2005).

In the plains, a low-cost and sustainable approach should consider breaches to be made and maintained in the embankments that line the river, so that controlled flows of water and sediment can be released down old channels on the Kosi River. By allowing controlled releases of sediment and water during high flows of the Kosi, at levels which can be adequately conveyed by each of the old channels, the uncontrolled and catastrophic shift of the river system could be avoided. This approach would also decrease pressure on the existing flood defences.

The embankments along with rail-road network in the Kosi region have also caused severe drainage congestion resulting in a much longer period of inundation and extensive water logging. Reinstatement of drainage pathway is an urgent need. The paleochannels on the Kosi fan is needed to be identified and reactivated by 


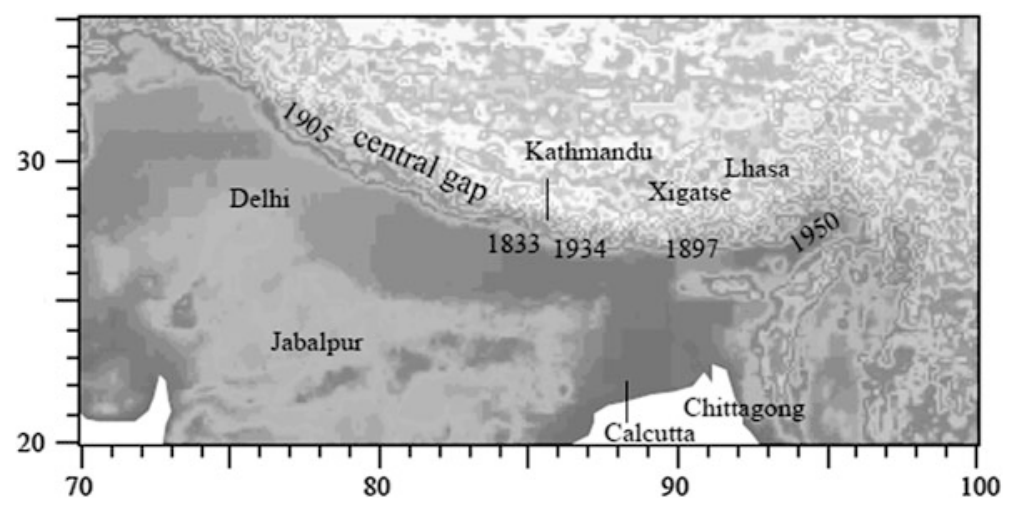

Fig. 7 Approximate Modified Mercalli Intensity VIII zones for five large earthquakes in the Himalaya since 1833 and settlements reporting information concerning the 1833 shock (white dots). A great earthquake may not have occurred in the $800 \mathrm{~km}$ segment of the Himalaya between the 1905 Kangra and 1934 Bihar earthquakes (Central Gap) for 650 years (Bilham 1995)

connecting them to the main channel using regulation structures and can be maintained as natural channels.

The use of modern technologies such as remote sensing and GIS, GPS-based surveys and echo sounding for river bed and floodplain mapping must be adopted on a routine basis and the database should be continuously updated.

In KRB management, an integrated plan involving all stakeholders (Nepal, India and China) is necessary. It should include engineering and non-engineering methods. Short-term and near future projects should include small-scale dams, strengthening of conservation areas, watershed management, irrigation and hydropower projects in the upper reaches of the basin, and focus on employment generating small-scale eco-friendly industries such as tourism. Long-term targets should include sustainable development, inter-river linkage canal systems, scientific agriculture systems, integrated watershed management, payment for environment and resilience to disasters. Good science, good technology and equitable basin-wise development can succeed in getting support from concerned local communities which leads to further cooperation and trust among the member countries.

\section{References}

Bilham R (1995) Location and magnitude of the 1833 Nepal earthquake and its relation to the rupture zones of contiguous great Himalayan earthquakes. Curr Sci 69(2):155-187

Chakraborty T, Kar R, Ghosh P, Basu S (2010) Kosi megafan: historical records, geomorphology and the recent avulsion of the Kosi river. Quat Int 227:143-160

Dixit A (2008) Two neighbors water course (Nepali language). Action Aid Nepal, Kathmandu Nepal 
Durham Report (2011): Workshop on 'River dynamics and flood hazard assessment with special reference to the Kosi River' 23 March 2011, Patna, India. Published by the Institute of Hazard, Risk and Resilience, Durham University 2011. Available at http://www.dur.ac.uk/ resources/ihrr/KosiRiverreport-IHRR.pdf Accessed 15 May 2011

Gole CV, Chitale SV (1966) Inland delta building activity of Kosi river. J Hydraul Div Am Soc Civil Eng 92:111-126

Kashiwai J (2005), Reservoir sedimentation and sediment management in Japan. Technical 259 memorandum of Public Works Research Institute, vol 3957, pp 240-250

Kattelmann R (1991). Hydrology for the water management of large river basins (proceedings of the Vienna symposium, August 1991). IAHS Publication No. 201

Mishra DK (2008). Serpent tied around the neck: Kosi embankment (Hindi Language). Patna, India, Freedom from Floods Campaign

Pun SB (2009) The Kosi Pralaya could the catastrophe have been averted? and what next? HydroNepal. J Water, Eng Environ 4:2-7

Salman SMA, Uprety K (2002) The Kosi River, in conflict and cooperation on South Asia's international rivers. A legal perspective, Van Puymbroeck (ed) The World Bank, Washington DC. Available at http://www-wds.worldbank.org/external/default/WDSContentServer/ WDSP/IB/2003/03/29/000094946_03031804015731/Rendered/PDF/multi0page.pdf Accessed 9 May 2012

Shrestha RK, Ahlers R, Bakker M, Gupta J (2010) Institutional dysfunction and challenges in flood control: a case study of the Kosi flood 2008. Economic \& Political Weekly vol 45(2), pp 45-53, 9 Jan 2010

Shrestha RK, Ahlers R, Bakker M and Gupta J. Institutional dysfunction and challenges in flood control along the transboundary Kosi River: A Case study of the Kosi Flood 2008. Available at http://www.earthsystemgovernance.org/ac2009/papers/AC2009-0496.pdf (Accessed 23 June 2012)

Sinha R (2009) Dynamics of a river system - the case of the Kosi River in North Bihar. e-J Earth Sci India 2:33-45

Thapa AB. The sorrow of Bihar: Kosi River. Available at http://madhesi.wordpress.com/tag/kosi/ (Acessed 23 June 2012) 